\title{
High-performance ultraviolet-visible tunable perovskite photodetector based on solar cell structure
}

\author{
Mengni Xue, Hai Zhou*, Yang Xu, Jun Mei, Lu Yang, Cong Ye, Jun Zhang and Hao Wang*
}

\begin{abstract}
An ultraviolet (UV)-visible tunable photodetector based on $\mathrm{ZnO}$ nanorod arrays (NAs)/perovskite heterojunction solar cell structures is presented, in which the $\mathrm{ZnO}$ NAs are prepared using the hydrothermal method and annealed in different atmospheres. Based on solar cell structure perovskite photodetectors, it exhibited highly repeatable and stable photoelectric response characteristics. In addition, the devices with $\mathrm{ZnO}$ NAs annealed in a vacuum showed a high responsivity of about $10^{14} \mathrm{~cm} \mathrm{~Hz}^{1 / 2} \mathrm{~W}^{-1}$ in the visible region, whereas the devices with $\mathrm{ZnO}$ NAs annealed in air exhibited good detectivity in the UV region, especially at around $350 \mathrm{~nm}$. Furthermore, when the annealing atmosphere of the $\mathrm{ZnO}$ nanorods was changed from vacuum to air, the dominant detection region of the photodetectors was altered from the visible to the ultraviolet region. These results enable potential applications of the $\mathrm{ZnO} \mathrm{NAs} /$ perovskite photodetectors in ultraviolet and visible regions.
\end{abstract}

Keywords: annealing, UV-vis tunable, $\mathrm{ZnO}$ nanorod arrays, perovskite

\section{INTRODUCTION}

In the past decade, perovskite materials have progressed rapidly. Since they were first used in dye-sensitized solar cells [1], the power-conversion-efficiency (PCE) of perovskite solar cells has increased from about $4 \%$ to more than $20 \%$ in the last seven years [2-5]. Perovskite materials have many advantages, including a direct band gap with a large absorption coefficient, high electrical mobility, long charge carrier lifetime, and long diffusion length [6-11]. In perovskite solar cells, some scaffold materials, such as $\mathrm{Al}_{2} \mathrm{O}_{3}, \mathrm{TiO}_{2}$, and $\mathrm{ZnO}$, have been widely used [4,12-14]. Of these, $\mathrm{ZnO}$ nanostructures have been extensively investigated mainly because they are environmentally friendly and cheap with a wide bandgap of $3.3 \mathrm{eV}$ at room temper- ature, and have a large exciton binding energy of $60 \mathrm{meV}$ [15-17]. However, it has been discovered that in these devices, the $\mathrm{ZnO}$ nanostructures have been treated either with the annealing process or without. Details on the effects of thermal annealing in different atmospheres on the performance of the devices have been seldom reported.

Perovskite solar cells are not only used as energy conversion devices but can also act as photodetectors [18-24]. In reports by Lin et al. [18], their photodetectors possessed a high detectivity beyond $10^{12}$ Jones and a PCE of more than $12 \%$. A self-powered, ultraviolet-visible (UV-vis) perovskite photodetector based on $\mathrm{TiO}_{2}$ nanorods was also reported with a PCE of $6.95 \%$ and the device exhibited good UV-visible photoresponse characteristics with a responsivity at zero bias reaching approximately 0.26 and $0.85 \mathrm{~A} \mathrm{~W}^{-1}$ at 364 and $494 \mathrm{~nm}$, respectively [19]. We found that all the perovskite materials in these devices were used as a light absorbing layer. In this work, we present a self-powered photodetector based on $\mathrm{ZnO}$ nanorod arrays (NAs)/perovskite heterojunction solar cell structures with UV-vis tunable photoresponse characteristics. In our devices, the perovskite material can not only be used as a light absorbing layer but also function as a p-type material. In addition, the $\mathrm{ZnO}$ NAs as an n-type light absorbing layer were treated by post-annealing to reduce the carrier concentration associated with oxygen vacancies, resulting in UV-vis tunable photoresponse characteristics.

\section{EXPERIMENTAL SECTION}

\section{Materials and device fabrication}

A fluorine-doped tin oxide (FTO)-coated glass substrate ( $14 \Omega /$ sq sheet resistivity) was cleaned using deionized water, acetone, and alcohol, in that sequence, for $15 \mathrm{~min}$ and

Hubei Collaborative Innovation Center for Advanced Organic Chemical Materials, Hubei Key Laboratory of Ferroelectric and Dielectric Materials and Devices, Faculty of Physics and Electronic Science, Hubei University, Wuhan 430062, China

*Corresponding authors (emails: hizhou34@126.com (Zhou H); nanoguy@126.com (Wang H)) 
was then cleaned in a UV ozone atmosphere for $30 \mathrm{~min}$. A $\mathrm{ZnO}$ seed layer was deposited on the FTO substrate using the spin coating method. A $0.15 \mathrm{~mol} \mathrm{~L}^{-1}$ solution of zinc acetate dihydrate $\left(\mathrm{Zn}\left(\mathrm{CH}_{3} \mathrm{COO}\right)_{2} \cdot 2 \mathrm{H}_{2} \mathrm{O}\right)$ was completely dissolved in methanol and was then spin-coated on the FTO glass at $4000 \mathrm{rpm}$ for $20 \mathrm{~s}$. Then, the samples were transferred into a muffle furnace to be annealed for $2 \mathrm{~h}$. After annealing, $0.6 \mathrm{~g}$ of polyethylenimine (PEI), $50 \mathrm{mmol} \mathrm{L}^{-1}$ of zinc nitrate hexahydrate $\left(\mathrm{Zn}(\mathrm{NO})_{3} \cdot 6 \mathrm{H}_{2} \mathrm{O}\right)$, and $30 \mathrm{mmol}$ $\mathrm{L}^{-1}$ of hexamethylenetetramine $\left(\mathrm{C}_{6} \mathrm{H}_{12} \mathrm{~N}_{4}\right)$ were dissolved after stirring for $30 \mathrm{~min}$. The $\mathrm{pH}$ was maintained between 10.6 and 10.8. The $\mathrm{ZnO}$ NAs were grown using the hydrothermal method at $90^{\circ} \mathrm{C}$ for $2 \mathrm{~h}$. The annealing treatment was carried out at $350^{\circ} \mathrm{C}$ for $2 \mathrm{~h}$ in air and vacuum.

The perovskite as a light absorbing layer was prepared using the two-step method. First, 1 mol L ${ }^{-1}$ of $\mathrm{PbI}_{2}$ was dissolved in $\mathrm{N}, \mathrm{N}$-dimethylformamide (DMF) solution and was then maintained at $70^{\circ} \mathrm{C}$ for $15 \mathrm{~h}$ until the $\mathrm{PbI}_{2}$ was completely dissolved. Subsequently, $\mathrm{CH}_{3} \mathrm{NH}_{3} \mathrm{I}$ was dissolved in the isopropyl alcohol solution and was stirred for $10 \mathrm{~min}$. $\mathrm{CH}_{3} \mathrm{NH}_{3} \mathrm{I}$ was synthesized using the method described by Lee et al. [22]. Hydroiodic acid ( $30 \mathrm{~mL}, 0.227$ mol, $57 \mathrm{wt} . \%$ in water, Aldrich) and methylamine (27.8 $\mathrm{mL}, 0.273 \mathrm{~mol}, 40 \%$ in methanol, TCI) were mixed and stirred in an ice bath for $2 \mathrm{~h}$. After stirring at $0^{\circ} \mathrm{C}$ for $2 \mathrm{~h}$, the resulting solution was evaporated at $50^{\circ} \mathrm{C}$ for $1 \mathrm{~h}$, generating the chemicals $\left(\mathrm{CH}_{3} \mathrm{NH}_{3} \mathrm{I}\right)$. The $\mathrm{PbI}_{2}$ solution was spin-coated onto the $\mathrm{ZnO}$ NAs at $3000 \mathrm{rpm}$ for $30 \mathrm{~s}$ and was then dried at $70^{\circ} \mathrm{C}$ for $10 \mathrm{~min}$. When it was completely dry, the film was dipped into a solution of $\mathrm{CH}_{3} \mathrm{NH}_{3} \mathrm{I}$ for 2 min. Finally, the samples above were annealed at $70^{\circ} \mathrm{C}$ for $30 \mathrm{~min}$.

After the deposition of perovskite materials, a hole transport material, which consisted of $55 \mathrm{mmol} \mathrm{L}^{-1}$ of 4-tert-butylpyridine (TBP), $26 \mathrm{mmol} \mathrm{L}^{-1}$ of lithium bis(trifluoromethylsulfonyl)imide (Li-TFSI), and $68 \mathrm{mmol} \mathrm{L}^{-1}$ of spiro-OMeTAD dissolved in acetonitrile and chlorobenzene $(1: 10, v / v)$, was coated on the perovskite film by spin-coating at a speed of $2000 \mathrm{rpm}$ for $30 \mathrm{~s}$. Finally, the 50 -nm-thick Au electrode was deposited by thermal evaporation under a pressure of $5 \times 10^{-5}$ Torr. The structure of the devices is illustrated in Fig. 1.

\section{Characterization}

The morphology and crystallinity of the samples were characterized by field emission scanning electron microscopy (FE-SEM, JEOL, JSM-6700F) and X-ray diffraction (XRD, D8 FOCUS X-ray diffraction), respectively. The photovoltaic properties of the cells were measured with a solar

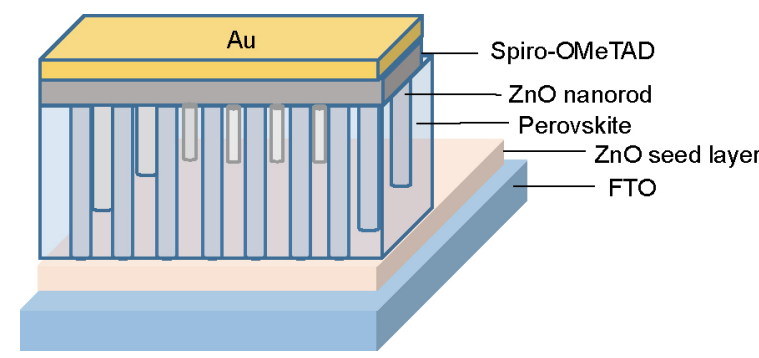

Figure 1 Structure of the $\mathrm{ZnO} \mathrm{NA}$ /perovskite heterojunction device.

simulator (Newport 69920, powder supply) under an AM $1.5 \mathrm{G}$ illumination at $1000 \mathrm{~W} \mathrm{~m}^{-2}$. The current-voltage $(I-V)$ and current density-voltage $(J-V)$ characteristics were measured by a Keithley 4200 electrometer. The photosensitivity was performed using a $66984 \mathrm{Xe}$ Arc source (300 W Oriel) and Oriel Cornerstone ${ }^{\mathrm{TM}} 260$ 1/4 m Monochromator. The sample was under direct illumination and the optical power of light was measured by a UV-enhanced Si detector.

\section{RESULTS AND DISCUSSION}

Fig. 2a and $b$ displays the surface and cross-section SEM images of the $\mathrm{ZnO}$ nanorods, and Fig. $2 \mathrm{c}$ and d displays the surface and cross-section SEM morphology of the $\mathrm{ZnO} /$ perovskite structure, respectively. We can observe that the surface of the $\mathrm{ZnO}$ typically has a regular hexagonal structure and the length of a $\mathrm{ZnO}$ nanorod is approximately $800 \mathrm{~nm}$. The top view of the $\mathrm{ZnO} /$ perovskite structure reveals that the perovskite completely covers the $\mathrm{ZnO}$ surface. There is no gap and the diameter of the perovskite is about $200-300 \mathrm{~nm}$. From the $\mathrm{ZnO}$ /perovskite cross-section, it is observed that the perovskite has completely permeated into the $\mathrm{ZnO}$ NAs. The crystal structure of $\mathrm{ZnO}$ NAs characterized through XRD in different annealing atmospheres is shown in Fig. 2e. We can observe a wurtzite crystal structure with a $c$-axis orientation of NAs for all the samples. Fig. $2 \mathrm{f}$ shows the absorption of the $\mathrm{ZnO} N A s$ and the $\mathrm{CH}_{3} \mathrm{NH}_{3} \mathrm{PbI}_{3}$ on $\mathrm{ZnO}$ NAs. In Fig. $2 \mathrm{f}$, the region of main $\mathrm{UV}$ absorption is attributed to $\mathrm{ZnO}$, while that of visible absorption is due to $\mathrm{CH}_{3} \mathrm{NH}_{3} \mathrm{PbI}_{3}$. Thus, based on the above absorption characteristics, the photoresponse of the $\mathrm{ZnO}$ NAs/perovskite heterojunction should be performed in UV and visible regions.

Fig. 3a presents the $J-V$ characteristic curves of the solar cell devices measured under an AM 1.5G illumination at $1000 \mathrm{~W} \mathrm{~m}^{-2}$ and the parameters determined from Fig. $3 \mathrm{a}$ are displayed in Table 1 . Table 1 indicates that the cell without $\mathrm{ZnO}$ annealing shows a short-circuit current density $\left(J_{\text {sc }}\right)$ of $21.2 \mathrm{~mA} \mathrm{~cm}^{-2}$, open-circuit voltage $\left(V_{\text {oc }}\right)$ of 0.87 
a

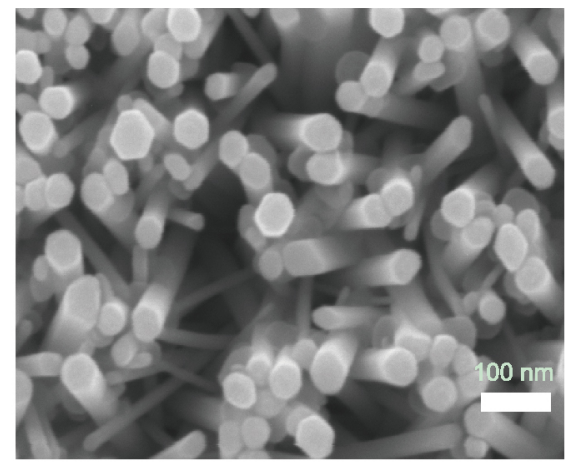

c
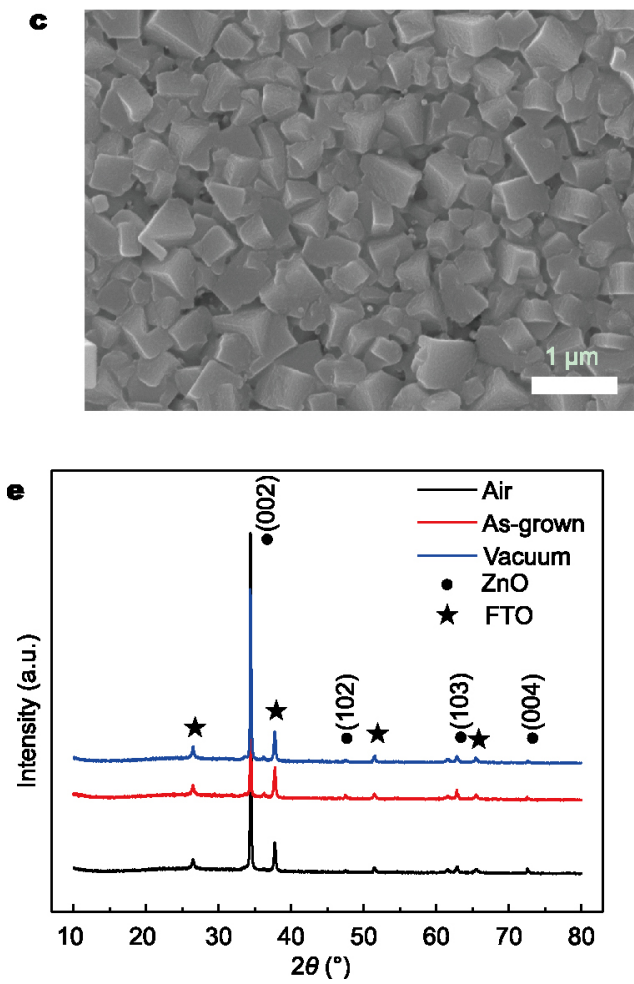

6

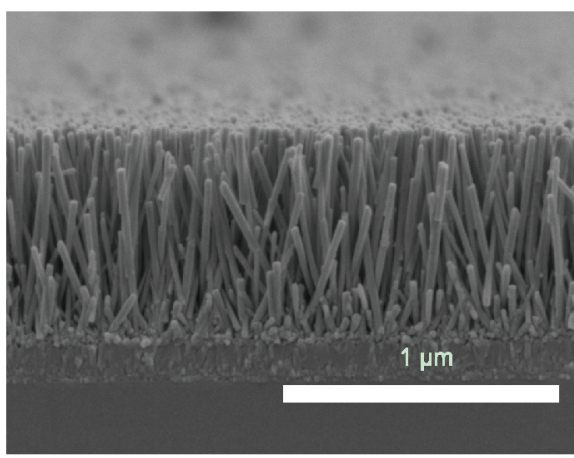

$d$
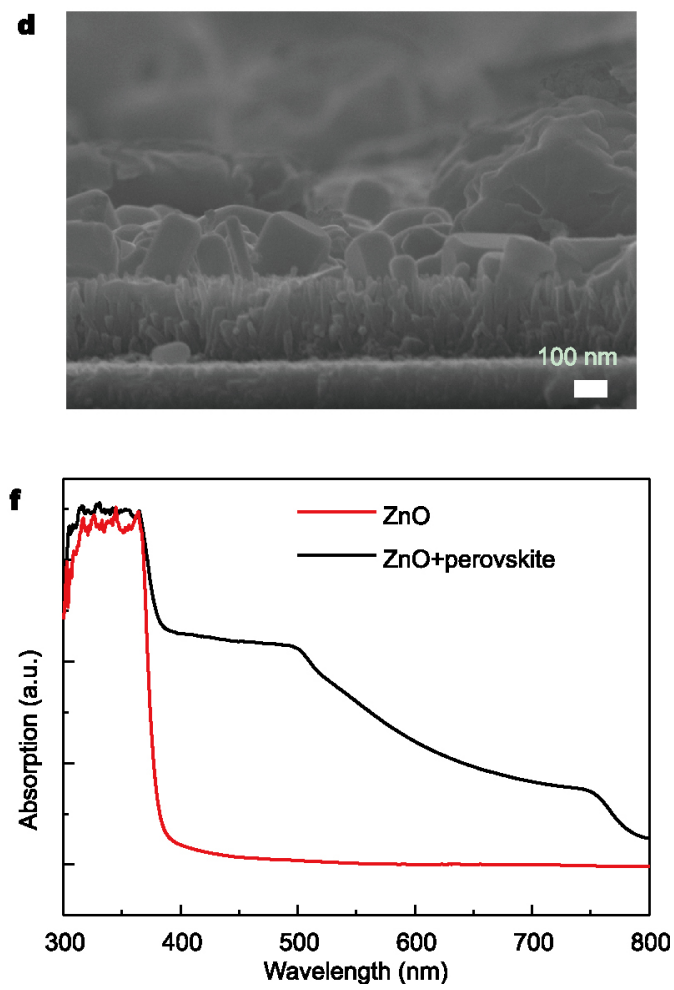

Figure 2 (a, b) Top view and cross-section of the ZnO NAs SEM morphology. (c, d) Top view and cross-section of the perovskite SEM morphology. (e) XRD of the ZnO NAs without annealing and with annealing in air and vacuum, respectively. (f) Absorption of the ZnO NAs and ZnO NAs/perovskite.

V, fill factor (FF) of 51.48\%, and high PCE of 9.65\%. Meanwhile, the cell with $\mathrm{ZnO}$ annealing in a vacuum exhibits the highest $\mathrm{FF}$ and the cell with $\mathrm{ZnO}$ annealing in air shows the lowest PCE. The decrease in PCE may be attributed to the annealing treatment, which will decrease the carrier density, resulting in a decrease in electrical conductivity and increase in series resistor. The inset of Fig. 3a presents the Ohmic contact curve between the hole transporting layer and gold electrode, which indicates that $\mathrm{Au}$ is a good choice as the top electrode, which is consistent with a previous report [23].

The dark $I-V$ curves and $I_{\mathrm{ph}} / I_{\mathrm{dark}}$ ratios (the ratio of photocurrent to dark current) of the devices, demonstrating strong anti-noise ability and weak light detection [24], are shown in Fig. $3 b$ and c, respectively, and we can note that all devices exhibit good diode rectifier characteristics with little dark current and maintain a high $I_{\mathrm{ph}} / I_{\text {dark }}$ ratio exceeding $10^{3}$, especially at zero bias.

Fig. 4a presents the spectral responsivity curves obtained from $\mathrm{ZnO} \mathrm{NAs} /$ perovskite heterojunctions at $0 \mathrm{~V}$. From the curves, we can observe that from 300 to $800 \mathrm{~nm}$, the responsivity of all devices decreases at $650 \mathrm{~nm}$, and the $\mathrm{ZnO}$ NAs annealed in a vacuum, as well as those without annealing, reach maximum values at $450 \mathrm{~nm}$ in which the region is attributed to the perovskite, while the $\mathrm{ZnO}$ NAs annealed in air reach a peak value at $365 \mathrm{~nm}$. The reason may be that 

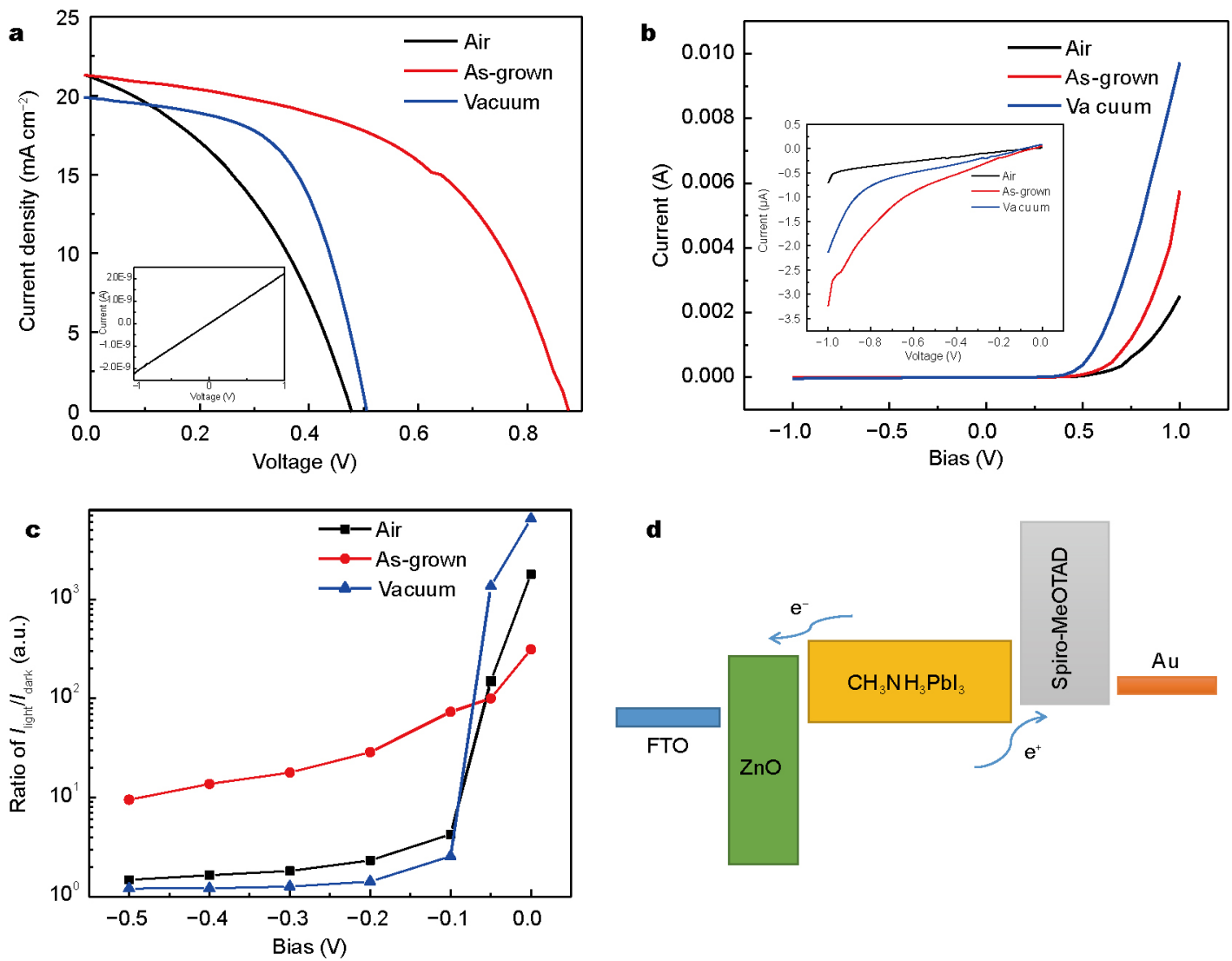

Figure 3 (a) $J-V$ characteristic curves of the solar cell devices. (b) Dark current of devices in different annealing atmospheres. The inset image shows a different dark current at a negative bias. (c) Ratio of photocurrent to dark current at reverse biases. (d) Schematic of ZnO NA/perovskite solar cell heterojunction device.

Table 1 Performance parameters of solar cells

\begin{tabular}{ccccc}
\hline & $V_{\mathrm{oc}}(\mathrm{V})$ & $J_{\mathrm{sc}}\left(\mathrm{mA} \mathrm{cm}^{-2}\right)$ & $\mathrm{FF}$ & $\mathrm{IF}$ \\
\hline Air & 0.48 & 21.0 & 39.57 & $4.65 \%$ \\
As-grown & 0.87 & 21.2 & 51.48 & $9.56 \%$ \\
Vacuum & 0.51 & 20.0 & 57.41 & $6.71 \%$ \\
\hline
\end{tabular}

for the devices, when the $\mathrm{ZnO}$ NAs are annealed in air, the oxygen vacancies decrease, decreasing the carrier concentration. According to the equation $N_{\mathrm{A}} X_{\mathrm{p}}=N_{\mathrm{D}} X_{\mathrm{n}}$, the depletion region is mainly in $\mathrm{ZnO}$, thus, the photogenerated carriers are mainly produced in $\mathrm{ZnO}$ and the responsivity of $\mathrm{ZnO}$ NAs annealed in air reaches a peak value at $365 \mathrm{~nm}$. Moreover, we can notice that the highest value of the responsivity is $7.8 \mathrm{~A} \mathrm{~W}^{-1}$ for the device without annealing. Then, the responsivity values of all the devices decrease sharply and, at $365 \mathrm{~nm}$, the values reach another peak, which is attributed to the photon absorption property of $\mathrm{ZnO}$ in the UV region. This response trend indicates that our devices exhibit high responsivity in both the
UV and visible light regions.

When the dark current is dominated by the shot noise, the detectivity can be expressed by the following equation [21],

$$
D^{*}=\frac{R}{\left(2 q J_{\mathrm{d}}\right)^{1 / 2}}=\frac{J_{\mathrm{ph}}}{L_{\text {light }}} \frac{1}{\left(2 q J_{\mathrm{d}}\right)^{1 / 2}},
$$

where $R$ is the responsivity of the photodiode, $J_{\mathrm{d}}$ is the dark current, $J_{\mathrm{ph}}$ is the photocurrent density, and $L_{\text {light }}$ is the light intensity. The detectivity curves are presented in Fig. $4 \mathrm{~b}$. The approximate trend of detectivity is similar to the responsivity. From the curves, we can note that the device with $\mathrm{ZnO}$ NAs annealed in vacuum shows the highest detectivity, which exceeds $10^{14} \mathrm{~cm} \mathrm{~Hz}^{1 / 2} \mathrm{~W}^{-1}$ at $450 \mathrm{~nm}$ and is comparable to that reported in other papers (see Table 2) [25-27].

This may be due to its larger photocurrent and smaller dark current compared with the other devices at zero bias (in the inset of Fig. 3b). Fig. 4c presents the curves of the UV-vis ratio $\left(R_{365} / R_{450}\right)$. The results indicate that the $R_{365} /$ 

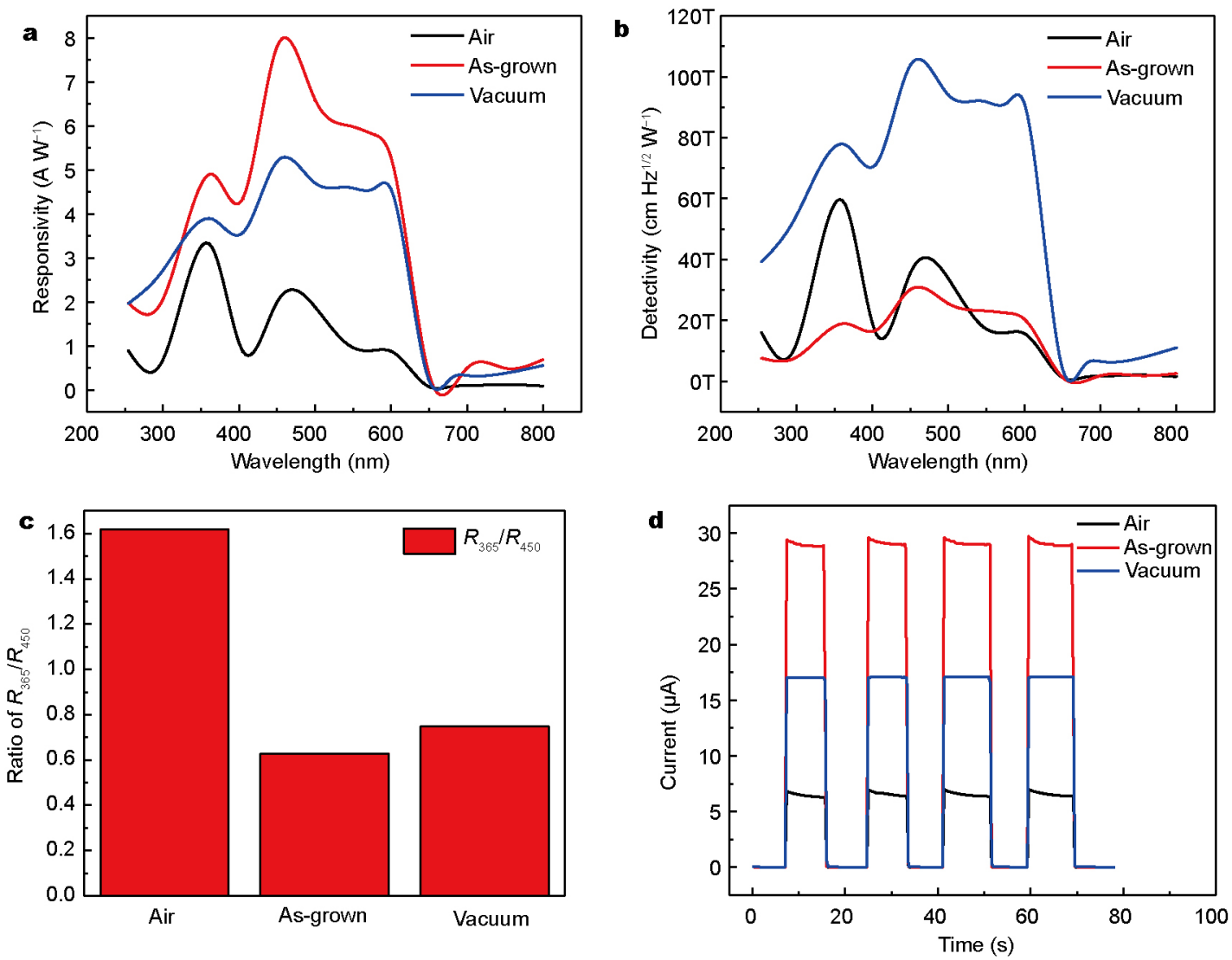

Figure 4 Spectral responsivity curve obtained at zero bias. (b) Spectral detectivity curve obtained at zero bias. (c) Ratio of responsivity at 365 and 500 nm. (d) Photocurrent with light-on and light-off cycles for the photodetectors at zero bias.

Table 2 Comparison with similar perovskite photodetector

\begin{tabular}{ccccc}
\hline Materials & Responsivity $\left(\mathrm{A} \mathrm{W}^{-1}\right)$ & Rise/decay time $(\mathrm{ms})$ & On/off ratio & Reference \\
\hline $\mathrm{CH}_{3} \mathrm{NH}_{3} \mathrm{PbI}_{3}$ & 7.8 & $288 / 322$ & $>10^{3}$ & This work \\
$\mathrm{CH}_{3} \mathrm{NH}_{3} \mathrm{PbI}_{3}$ & 0.85 & $\sim$ & $\sim$ & {$[19]$} \\
$\mathrm{CH}_{3} \mathrm{NH}_{3} \mathrm{PbI}_{3}$ & 23 & $150 / 150$ & $\sim$ & {$[25]$} \\
$\mathrm{CH}_{3} \mathrm{NH}_{3} \mathrm{PbI}_{3}$ & 1.32 & $0.3 / 0.3$ & $\sim 26]$ \\
$\mathrm{CH}_{3} \mathrm{NH}_{3} \mathrm{PbI}_{3}$ & $5 \times 10^{-3}$ & $0.5 / 0.5$ & {$[27]$} \\
\hline
\end{tabular}

$R_{450}$ ratio of the device with the $\mathrm{ZnO}$ NAs annealed in air is greater than 1 (about 1.6), which displays a UV-dominant response mode. However, for the $R_{365} / R_{450}$ ratio of the device with the $\mathrm{ZnO}$ NAs annealed in vacuum or without annealing, which is less than 1 (about 0.6 and 0.7 , respectively), it exhibits a visible dominant response mode. Therefore, we can conclude that we can achieve a UV-vis tunable photodetector by changing the $\mathrm{ZnO}$ NAs annealing conditions.

In our devices, the photoresponse behavior of the $\mathrm{ZnO}$ $\mathrm{NAs} / \mathrm{CH}_{3} \mathrm{NH}_{3} \mathrm{PbI}_{3}$ heterojunction was characterized by measuring the current as a function of time at zero bias when the light was periodically turned on and off, as shown in Fig. 4d. The results indicate that at room temperature, our ZnO-based perovskite photodetector possesses great repeatability and stability characteristics. Meanwhile, at $450 \mathrm{~nm}$, the as-grown sample exhibits the highest photocurrent. In addition, the response time of the devices is small with the rise and fall time of 288 and $322 \mathrm{~ms}$, respectively.

Oxygen vacancies in the $\mathrm{ZnO}$ NAs are very important for the performance of the photodetector, which has been analyzed by X-ray photoelectron spectroscopy (XPS) and presented in Fig. 5. There are three peaks labeled as low 
peak (LP), middle peak (MP), and high peak (HP), which are centered at $530.4,531.5$, and $532.4 \mathrm{eV}$, respectively [28]. Hererin, the LP is attributed to the $\mathrm{Zn}-\mathrm{O}$ bonds for the wurtzite structure and the HP is usually attributed to chemisorbed oxygen. The MP is associated with $\mathrm{O}^{2-}$ in the oxygen-deficient regions with the matrix of $\mathrm{ZnO}$, and the intensity of MP is related to the variations in concentration of oxygen vacancies [29]. From the figures, we can notice that the $\mathrm{ZnO}$ NRs without annealing displays a large number of oxygen vacancies. When the ZnO NRs are annealed in vacuum, the crystal quality of $\mathrm{ZnO}$ NRs improves, but the oxygen vacancies decrease by a small amount because of the entry without oxygen in vacuum. For annealing in air, the oxygen vacancies of the $\mathrm{ZnO}$ decrease significantly.

In the $\mathrm{ZnO}$-based perovskite photodetectors, $\mathrm{ZnO}$ acts as an n-type material, while perovskite acts as a p-type material (the schematic is shown in Fig. 3d). Under illumination, when the energy of the photons is larger than the band gap of the semiconductor, the light will be absorbed and the electron-hole pairs will be generated in the depletion layer. Under the internal electric field, electron-hole pairs will be separated at the $\mathrm{ZnO} /$ perovskite interface. Electrons arrive at the FTO anode and holes arrive at the Au cathode. Based on this, the device captures the light signal and converts it into an electric signal. For a unit area of the $p-n$ junction, all negative-space charges at the p-type side are equal to all positive-space charges at the $\mathrm{n}$-type side, i.e.,

$$
N_{\mathrm{A}} x_{\mathrm{p}}=N_{\mathrm{D}} x_{\mathrm{n}},
$$

where $N_{\mathrm{A}}$ is the acceptor impurity concentration, $x_{\mathrm{p}}$ is the width of the p-type depletion layer, $N_{\mathrm{D}}$ is the donor impurity concentration, and $x_{\mathrm{n}}$ is the width of the n-type depletion layer. Thus, from the equation above, the higher impurity concentration in the semiconductor will result in a smaller depletion layer width in this layer. Based on the photoresponse mechanism, the small $R_{365} / R_{450}$ ratio of the device with the $\mathrm{ZnO}$ NAs annealed in vacuum or without annealing indicates that the carrier concentration of the $\mathrm{ZnO}$ NAs is very large. This is because before annealing, the existence of many defects, especially oxygen vacancies (Fig. 5a and b), results in a high carrier density [30,31]. Therefore, the depletion layer is mainly located at the side
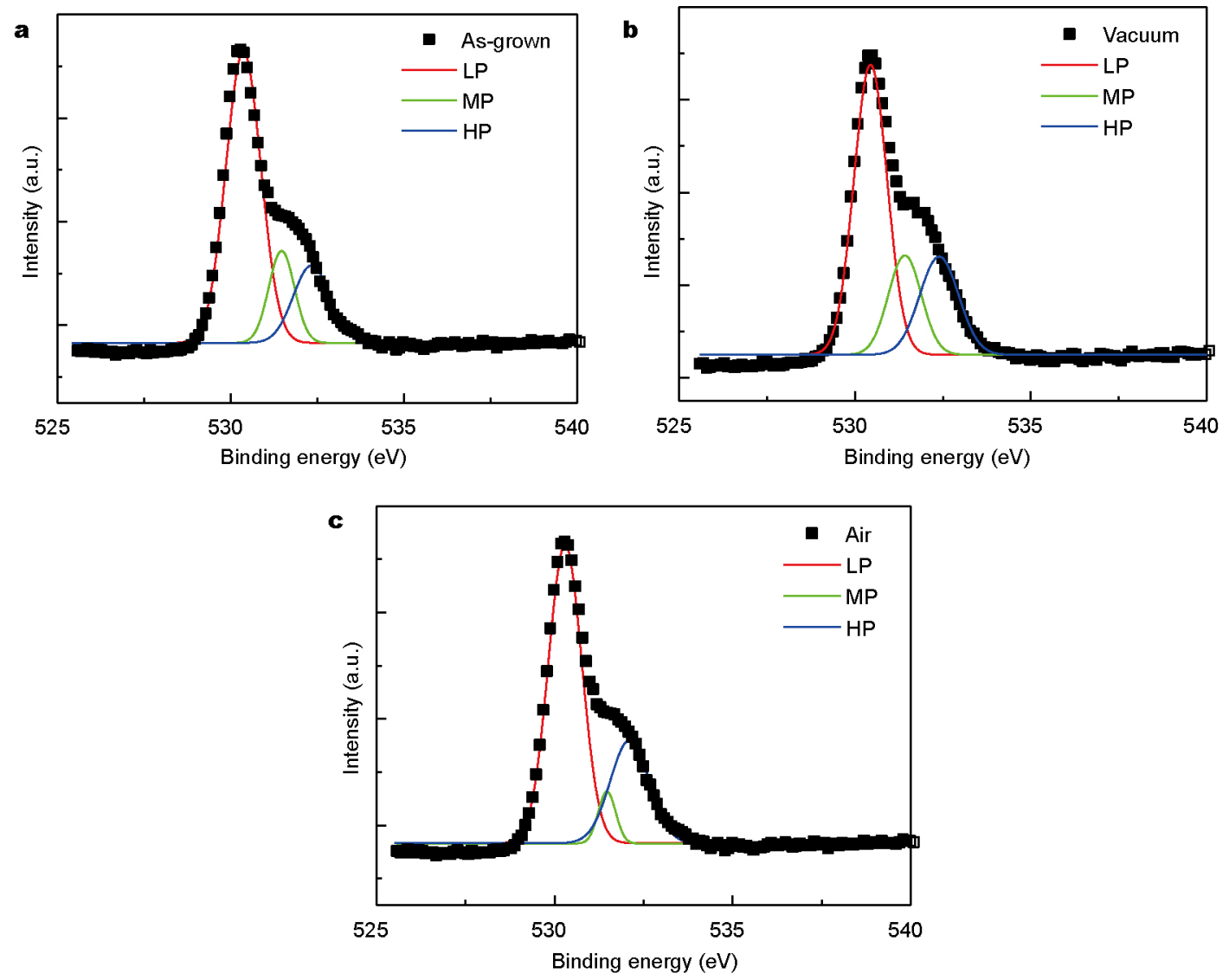

Figure 5 O 1s XPS spectroscopic spectra of the ZnO NAs (a) obtained without annealing, (b) annealed in vacuum, and (c) annealed in air. 
of the perovskite, and the devices with the ZnO NAs annealed in vacuum as well as those without annealing show a visible dominant response trend. However, when the $\mathrm{ZnO}$ NAs are annealed in air, the inherent defects of $\mathrm{ZnO}$ NAs synthesized by the hydrothermal method and the defect-related carrier density will decrease, resulting in a decrease in carrier density [32]. Thus, the device with the $\mathrm{ZnO}$ NAs annealed in air shows a large $R_{365} / R_{450}$ ratio and UV-dominant response trend. We can conclude that the UV-vis tunable photodetector can operate based on the $\mathrm{ZnO}$ NAs/perovskite heterojunction solar cell structure through annealing treatment in different atmospheres.

\section{CONCLUSIONS}

We presented a UV-vis, tunable, self-powered photodetector based on a $\mathrm{ZnO} \mathrm{NA} /$ perovskite solar cell structure, and the $\mathrm{ZnO}$ NAs experienced different annealing conditions. We presented a solar cell that possessed a PCE of $9.56 \%$ without annealing. Meanwhile, the devices demonstrated good photoelectric properties at $0 \mathrm{~V}$ with the highest responsivity of $7.8 \mathrm{~A} \mathrm{~W}^{-1}$ for the devices without annealing and a detectivity of $10^{14} \mathrm{~cm} \mathrm{~Hz}^{1 / 2} \mathrm{~W}^{-1}$ for the devices with the $\mathrm{ZnO}$ NAs annealed in vacuum. Furthermore, our devices demonstrated UV-vis tunable characteristics through annealing treatment in different atmospheres.

Received 1 March 2017; accepted 29 March 2017; published online 17 April 2017

1 Kojima A, Teshima K, Shirai Y, et al. Organometal halide perovskites as visible-light sensitizers for photovoltaic cells. J Am Chem Soc, 2009, 131: 6050-6051

2 Zhou $\mathrm{H}$, Chen Q, Li G, et al. Interface engineering of highly efficient perovskite solar cells. Science, 2014, 345: 542-546

3 Yang WS, Noh JH, Jeon NJ, et al. High-performance photovoltaic perovskite layers fabricated through intramolecular exchange. Science, 2015, 348: 1234-1237

4 Anaraki EH, Kermanpur A, Steier L, et al. Highly efficient and stable planar perovskite solar cells by solution-processed tin oxide. Energ Environ Sci, 2016, 9: 3128-3134

5 Fang Y, Huang J. Resolving weak light of sub-picowatt per square centimeter by hybrid perovskite photodetectors enabled by noise reduction. Adv Mater, 2015, 27: 2804-2810

6 Stranks SD, Eperon GE, Grancini G, et al. Electron-hole diffusion lengths exceeding 1 micrometer in an organometal trihalide perovskite absorber. Science, 2013, 342: 341-344

7 Xing G, Mathews N, Sun S, et al. Long-range balanced electronand hole-transport lengths in organic-inorganic $\mathrm{CH}_{3} \mathrm{NH}_{3} \mathrm{PbI}_{3}$. Science, 2013, 342: 344-347

8 Lee Y, Kwon J, Hwang E, et al. High-performance perovskite-graphene hybrid photodetector. Adv Mater, 2015, 27: 41-46

9 Liu C, Wang K, Yi C, et al. Ultrasensitive solution-processed perovskite hybrid photodetectors. J Mater Chem C, 2015, 3: 6600-6606
10 Saidaminov MI, Haque MA, Savoie M, et al. Perovskite photodetectors operating in both narrowband and broadband regimes. Adv Mater, 2016, 28: 8144-8149

11 Murali B, Saidaminov MI, Abdelhady AL, et al. Robust and air-stable sandwiched organo-lead halide perovskites for photodetector applications. J Mater Chem C, 2016, 4: 2545-2552

12 Guarnera S, Abate A, Zhang W, et al. Improving the long-term stability of perovskite solar cells with a porous $\mathrm{Al}_{2} \mathrm{O}_{3}$ buffer layer. J Phys Chem Lett, 2015, 6: 432-437

13 Son DY, Im JH, Kim HS, et al. $11 \%$ efficient perovskite solar cell based on $\mathrm{ZnO}$ nanorods: an effective charge collection system. J Phys Chem C, 2014, 118: 16567-16573

14 Kumar MH, Yantara N, Dharani S, et al. Flexible, low-temperature, solution processed $\mathrm{ZnO}$-based perovskite solid state solar cells. Chem Commun, 2013, 49: 11089-11091

15 Zhou H, Zhu Y, Wang $\mathrm{H}$, et al. Electroluminescence transition from visible- to ultraviolet-dominant mode in $\mathrm{n}-\mathrm{Mn}_{0.04} \mathrm{Zn}_{0.96} \mathrm{O} / \mathrm{i}$ $\mathrm{ZnGa}_{2} \mathrm{O}_{4} / \mathrm{n}$-GaN structure with highly ultraviolet detection performance. IEEE Electron Device Lett, 2013, 34: 423-425

$16 \mathrm{Xu} \mathrm{Y,} \mathrm{Liu} \mathrm{T,} \mathrm{Li} \mathrm{Z,} \mathrm{et} \mathrm{al.} \mathrm{Preparation} \mathrm{and} \mathrm{photovoltaic} \mathrm{properties} \mathrm{of}$ perovskite solar cell based on $\mathrm{ZnO}$ nanorod arrays. Appl Surface Sci, 2016, 388: 89-96

17 Zhou H, Gui P, Yu Q, et al. Self-powered, visible-blind ultraviolet photodetector based on $\mathrm{n}-\mathrm{ZnO}$ nanorods/i- $\mathrm{MgO} / \mathrm{p}-\mathrm{GaN}$ structure light-emitting diodes. J Mater Chem C, 2015, 3: 990-994

18 Lin Q, Armin A, Lyons DM, et al. Low noise, IR-blind organohalide perovskite photodiodes for visible light detection and imaging. Adv Mater, 2015, 27: 2060-2064

19 Zhou H, Song Z, Tao P, et al. Self-powered, ultraviolet-visible perovskite photodetector based on $\mathrm{TiO}_{2}$ nanorods. RSC Adv, 2016, 6: 6205-6208

20 Yu J, Chen X, Wang Y, et al. A high-performance self-powered broadband photodetector based on a $\mathrm{CH}_{3} \mathrm{NH}_{3} \mathrm{PbI}_{3}$ perovskite/ZnO nanorod array heterostructure. J Mater Chem C, 2016, 4: 7302-7308

21 Dou L, Yang YM, You J, et al. Solution-processed hybrid perovskite photodetectors with high detectivity. Nat Commun, 2014, 5: 5404

22 Lee MM, Teuscher J, Miyasaka T, et al. Efficient hybrid solar cells based on meso-superstructured organometal halide perovskites. Science, 2012, 338: 643-647

23 Ke W, Fang G, Wan J, et al. Efficient hole-blocking layer-free planar halide perovskite thin-film solar cells. Nat Commun, 2015, 6: 6700

24 Hu X, Zhang X, Liang L, et al. High-performance flexible broadband photodetector based on organolead halide perovskite. Adv Funct Mater, 2014, 24: 7373-7380

25 Huo C, Cai B, Yuan Z, et al. Two-dimensional metal halide perovskites: theory, synthesis, and optoelectronics. Small Methods, 2017, 1: 1600018

26 Li X, Cao F, Yu D, et al. All inorganic halide perovskites nanosystem: synthesis, structural features, optical properties and optoelectronic applications. Small, 2017, 13: 1603996

27 Li X, Yu D, Chen J, et al. Constructing fast carrier tracks into flexible perovskite photodetectors to greatly improve responsivity. ACS Nano, 2017, 11: 2015-2023

28 Zhou H, Fang GJ, Zhu Y, et al. Flexible resistive switching memory based on $\mathrm{Mn}_{0.20} \mathrm{Zn}_{0.80} \mathrm{O} / \mathrm{HfO}_{2}$ bilayer structure. J Phys D-Appl Phys, 2011, 44: 445101

29 Wang J, Wang Z, Huang B, et al. Oxygen vacancy induced bandgap narrowing and enhanced visible light photocatalytic activity of ZnO. ACS Appl Mater Interfaces, 2012, 4: 4024-4030

30 Ji LW, Peng SM, Su YK, et al. Ultraviolet photodetectors based on selectively grown $\mathrm{ZnO}$ nanorod arrays. Appl Phys Lett, 2009, 94: 
203106

31 Zhou H, Fang G, Liu N, et al. Ultraviolet photodetectors based on $\mathrm{ZnO}$ nanorods-seed layer effect and metal oxide modifying layer effect. Nanoscale Res Lett, 2011, 6: 147

32 Tam KH, Cheung CK, Leung YH, et al. Defects in $\mathrm{ZnO}$ nanorods prepared by a hydrothermal method. J Phys Chem B, 2006, 110: 20865-20871

Acknowledgments This work is supported by the National Nature Sci- ence Foundation of China (51372075).

Author contributions Xue $\mathrm{M}$, Zhou $\mathrm{H}$ and Wang $\mathrm{H}$ conceived and designed the experiments; Xue M, Xu Y, Mei J and Yang L performed the experiments; Xue M, Zhou H, Ye C and Zhang J analyzed the data; Ye C and Wang $\mathrm{H}$ contributed materials tools; Xue M, Zhou $\mathrm{H}$ and Wang $\mathrm{H}$ wrote the paper.

Conflict of interest The authors declare that there is no conflict of interest.

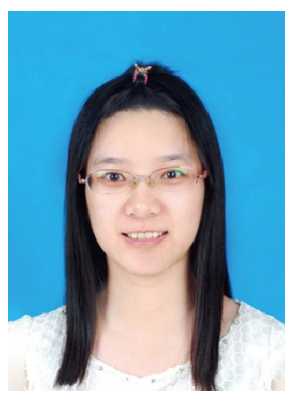

Mengni Xue received her bachelor's degree in science from Wuhan Institute of Technology, Wuhan, China. She is currently a graduate student in the Faculty of Physics and Electronic Science, Hubei University, Wuhan, China. Her main research areas include photodetectors and photoelectric devices based on perovskite materials.
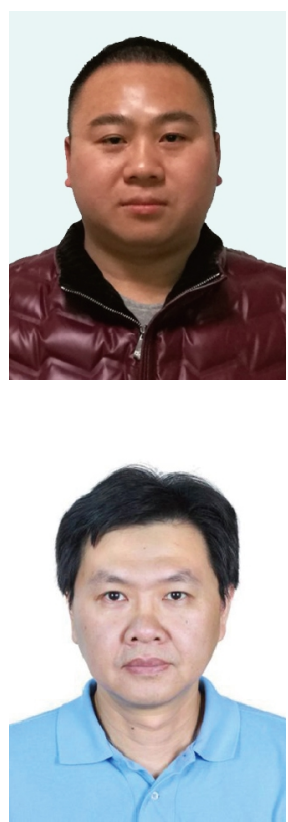

Hai Zhou received his $\mathrm{MSc}$ and $\mathrm{PhD}$ degrees in microelectronics and solid state electronics from Wuhan University, Wuhan, China. He is currently an associate professor of Hubei Collaborative Innovation Center for Advanced Organic Chemical Materials, Hubei Key Laboratory of Ferroelectric and Dielectric Materials and Devices, the Faculty of Physics and Electronic Science, Hubei University, Wuhan, China. His main research areas include self-power photodetectors, ultraviolet LEDs devices, and photoelectric devices based on perovskite materials.

Hao Wang is a Chair Professor of the Faculty of Hubei University. He received his PhD degree from Huazhong University of Science and Technology in 1994. He is a visiting professor of the University of Cambridge and Aalto University. He has published more than 150 peer reviewed papers (such as Adv. Energy Mater., ACS Nano, Nano Energy) and held 18 patents. His research interests involve solar cells, fuel cells, non-volatile memory, photodetectors and magnetic nanostructures.

\section{基于太阳电池结构高性能紫外-可见可调型钻钓矿探测器}

薛梦妮, 周海*, 许杨, 梅俊, 杨麓, 叶苟, 张军, 王浩*

摘要 本文报道了一种基于 $\mathrm{ZnO}$ 纳米棒阵列/钲钛矿电池结构的紫外-可见可调的光电探测器, 其中 $\mathrm{ZnO}$ 纳米棒阵列采用水热法制备并在不同 气氛下退火. 基于电池结构的钙钛矿光电探测器具有较好的光电响应重复性和稳定性. ZnO纳米棒阵列真空退火的器件在可见光区域达到 了 1014 Jones的响应度, 而ZnO纳米棒阵列在空气中退火的器件在紫外光区域, 尤其在 $365 \mathrm{~nm}$ 处有较好的探测性能. 进一步研究发现, 通过不 同氛围退火, 实现了紫外-可见可调的光电探测性能. 以上结果表明 $\mathrm{ZnO}$ 纳米棒阵列/钲钛矿光电探测器在紫外和可见光区域存在潜在应用. 